\title{
Wildlife Conservation and Management in Kenya: Towards a Co-management Approach \\ John Mburu
}

\author{
NOTA DI LAVORO 47.2004
}

\section{MARCH 2004}

NRM - Natural Resources Management

John Mburu, Center for Development Research (ZEF), University of Bonn

This paper can be downloaded without charge at:

The Fondazione Eni Enrico Mattei Note di Lavoro Series Index: http://www.feem.it/Feem/Pub/Publications/WPapers/default.htm

Social Science Research Network Electronic Paper Collection:

http://ssrn.com/abstract $=524543$

The opinions expressed in this paper do not necessarily reflect the position of

Fondazione Eni Enrico Mattei 


\title{
Wildlife Conservation and Management in Kenya: Towards a Co-management Approach
}

\begin{abstract}
Summary
The co-management approach of managing natural resources has increasingly become popular among conservationists and development practitioners since it overcomes the shortcomings of both the centralised management and community-based approaches that hinder harmonization of conflicting interests among diverse stakeholder groups. Considering criteria developed from theoretical advancements on co-management and drawing on empirical studies conducted in Kenya, the paper examines how successful the co-management approach has been in terms of meeting the needs and interests of local communities and conservationists. Further, it analyses some of the factors or conditions that contribute towards the emergence and subsequent adoption of the co-management approach in the conservation and management of wildlife. These factors, which may also be important in other developing countries, include the provision of a favourable policy framework, institutional capacity of organized user groups to co-manage wildlife resources, land tenure conditions and accessibility to wildlife resources. It is emphasised that the co-management approach has had, so far, mixed results and there are certain important factors challenging its successful implementation in Kenya.
\end{abstract}

Keywords: Kenya, Co-management, Wildlife management, Conditions for comanagement, Sustainable management

This paper has been presented at the $4^{\text {th }}$ BioEcon Workshop on "Economic Analysis of Policies for Biodiversity Conservation”, Venice, Italy, August 28-29, 2003, organised on behalf of the BIOECON Network by Fondazione Eni Enrico Mattei, Venice International University (VIU) and University College London (UCL).

Address for correspondence:

John Mburu

Center for Development Research (ZEF)

University of Bonn

Walter-Flex-Str. 3

D-53113 Bonn

Germany

Phone: +49-228-731915

Fax: +49-228-731689

Email: jmburu@uni-bonn.de 


\subsection{Evolution of Different Management Approaches of Wildlife Resources}

Searching for viable and sustainable strategies of wildlife conservation in developing countries, which are typically rich in biodiversity, traces back to the times when the fence and fines approach, also known as American National Park model, was commonly being applied (Borrini-Feyerabend, 1996: 5; Songorwa 1999: 2061; Venema and van den Breemer, 1999: 5). This led to the establishment of protected areas (PAs) or 'fortress parks and reserves' which did not condone wildlife consumptive utilisation and entailed high management costs for governments, with majority of the benefits not accruing to local communities. To enhance the biological integrity of the parks, this model has been adjusted to the more attractive "protected areas outreach" (PAO) model which encourages working and educating local communities and sharing with them some benefits (Barrow and Murphee, 2001: 32-33). However, with high population growth, governments's shrinking budgets and subordination of natural resources to short-term economic or political interests, neither the PAs nor PAO has succeeded in curbing biodiversity loss (Baland and Platteau, 1996: 420; Meinzen-Dick and Knox, 2001: 44-45). Thus, there has been a shift from this 'protectionist' concept or states' centralised management strategy towards a communitybased model, which emphasises on transfer of wildlife rights and responsibilities to local institutions.

Over the past two decades, several developing countries in Sub-Saharan Africa have adopted the community-based approach, which is often implemented in form of integrated conservation and development projects (ICDPs). Such projects include the Communal Area Management Programme for Indigenous Resources (CAMPFIRE) in Zimbabwe, Luangwa Integrated Rural Development Programme (LIRDP) in Zambia and Community-based Wildlife Management in Tanzania (CWM) (IIED, 1994; Virtanen, 2003). Although this approach has helped to tackle some of the shortcomings of the centralised and 'protectionist' approach, it has some significant limitations and obstacles to implementation and therefore some of the ICDPs have not been successful (Kiss, 1999: 14; Leach et al., 1999: 225; Songorwa 1999: 2062; Virtanen, 2003: 187). As documented by several authors (see for example Wainwright and Wehrmeyer, 1998: 934; Songorwa, 1999: 2068; Virtanen, 2003: 
187), most of these ICDPs have not only experienced low community participation but have also failed to achieve their conservation and development objectives, and to produce sufficient benefits that can improve communities' living standards.

Thus, although at first the community-based approach seemed quite promising as an effective and efficient tool in achieving both biodiversity conservation and socio-economic development goals, many conservationists are now recommending its review. Further, biodiversity conservation funding organisations (e.g. World Bank, bilateral donors, etc.) and international conservation non-governmental organisations are calling for the application of a combination of the states' centralised approach and the community-based models. Combining both models is regarded essential for ensuring sustainable biodiversity conservation since needs and interests of both conservation managers and local communities are fulfilled. 'Dangers of decentralisation and devolution' which arise due to certain resource characteristics (e.g. endangered species) could also be avoided (Lutz and Caldecott, 1996: 2). In supporting this view, Kiss (1999: 14) argues that "community-based conservation activities are essential for generating political support for conservation and reducing and mitigating human-wildlife conflicts, but they can rarely, if ever, fully substitute for direct protection of unique and valuable biodiversity resources".

\subsection{The Emergence of the Co-management Approach}

The failure of both the state-based and community-based models of managing wildlife and other natural resources to successfully fulfil goals of conservation and meet the socioeconomic needs of the local communities is regarded as the impetus for the evolution of collaborative management (in short, co-management) approach. The co-management approach (also sometimes referred to as participatory management, joint management, shared management, management in partnership, multi-stakeholder management or round table management) seeks to create negotiated agreements between the protected areas' managers and other interest groups, including local resource users (Hilhorst and Aarnink 1999; Borrini-Feyerabend et al., 2000). Within the current discourse on decentralisation and devolution of natural resource management authority to local organisations, the comanagement approach has increasingly gained support among the common-pool resource experts. It fits well into the devolution process because it seeks to complement the 
weaknesses or shortcomings of both the traditional or community-based natural resource management systems and the centralised strategies of the state.

Meinzen-Dick and Knox (2001: 41) emphasise that the co-management approach emerges when the state retains a substantial role in resource management, while the role of the local resource users or landowners is expanded. Thus, it is different from community-based approach, which is characterised by more or less complete control of the natural resources by the local user groups. Clear differences also arise from the focus of each of these two approaches. While the community-based approach is people-centred and communityfocused, the co-management strategy focuses more on a partnership arrangement between the government, resource users or landowners and other key stakeholders in the society, and has therefore a broader scope and scale (Pomeroy, 2001: 119-120).

Though co-management can positively contribute towards successful achievement of goals of conservation and socio-economic development, co-management arrangements cannot emerge or be effective without an enabling political framework and favourable government policies. A strong political support and enabling policies would particularly create incentives for the local resource users to participate fully in management partnerships and afford them protection from powerful outsiders (Borrini-Feyerabend et al., 2000). Co-management cannot also be regarded as a panacea to the problems of natural resources management, since, as evidenced from past studies, results of its feasibility and viability have been mixed. In the light of these arguments and drawing on empirical cases conducted in Kenya, this paper tackles two important issues that concern implementation of partnerships or comanagement projects. First, it looks at how the adoption of co-management approach has so far been dependent on the Kenyan wildlife conservation policy. Second, it examines how successful the co-management approach has been in fulfilling needs and interests of different stakeholder groups and mentions major challenges that are faced with the implementation of co-management initiatives in Kenya. The paper adds to the growing discourse on the relevant conditions for successful management of natural resources in developing countries, which, though known to be rich in biodiversity, lack the capacity for long-term sustainable management. 


\section{Shifts of Wildlife Management Strategies in Kenya in Relation to Policy}

In Kenya, which is one of the most developed wildlife-based tourism destinations in SubSaharan Africa (Sindiga, 1999), searching for a sustainable approach of managing wildlife traces back to the 1970's post-independent wildlife policy that gave emphasis to preservation of land occupied by wildlife leading to creation of numerous National Parks and Reserves ${ }^{1}$. Under this strategy, hunting was disallowed and tourism activities were limited to land within in the protected areas. Although the policy contributed towards reduction of wildlife losses in protected areas (Norton-Griffiths, 2000), it led to local communities being evicted from their ancestral land. Since the local communities never participated in the establishment of the protected areas, this policy neither provided for their interests nor gave them access to wildlife benefits. Moreover, with seventy percent of wildlife living outside protected areas either on permanent or seasonal basis, greater wildlife losses arose from outside the parks and reserves and therefore this strategy failed to support the objective of total protection.

The enactment of the Wildlife Act (also called the Wildlife Conservation and Management Act) by the Kenyan Parliament in 1977 (Western, 1994: 34) led to a major overhaul of the conservation policy. As indicated in Sessional Paper 3 of 1975 (Republic of Kenya, 1975: 13), the new policy called for direct negotiations on the future of wildlife in dispersal areas between the newly created Wildlife Conservation and Management Department (WCMD) and the local communities. However, due to an inadequate legal framework, political and bureaucratic interference, and corruption, the (WCMD) ${ }^{2}$ did not succeed in tackling the increased levels of human-wildlife conflicts and loss of biodiversity, which are the two major wildlife management problems it had been created to deal with (Kock, 1995; Honey, 1999). Further, the local communities, who bear both direct and indirect costs of living together with seventy per cent of wildlife, remained excluded from direct cash benefits that

\footnotetext{
${ }^{1}$ Currently the country has 26 National Parks, 28 National Reserves and one Sanctuary, which occupy 44000 $\mathrm{km}^{2}$ ( $8 \%$ of the total territory) and harbour about $25 \%$ of total wildlife populations (Watson, 1999: 1). About $75 \%$ of wildlife animals therefore live in privately owned lands, which are adjacent to these protected areas. The majority of the protected areas are situated in the savannah grasslands and semi-arid lands, which previously had been occupied by traditional pastoralists.

${ }^{2}$ The WCMD was formed by combining the National Parks Board and Game Department. Though the National Parks Board had professional staff, those of the Game Department were corrupt and had been politically misused. Also, WCMD was made a department under the Ministry of Tourism and Wildlife and therefore wildlife management continued being guided by top down policy decisions (Republic of Kenya, 1975: 4)
} 
could be derived from wildlife in their privately owned lands (Norton-Griffith, 2000: 13). The 'negotiating policy' could not allow initiation of management partnerships with local communities since it lacked a clear framework to facilitate its implementation.

In an attempt to improve the relationship between the state and landowners in the wildlife dispersal areas, and curb the biodiversity losses of the 1970s and 1980s, the Wildlife Act was amended in 1989 and WCMD was replaced with Kenya Wildlife Service (Barrow et al., 2001). As a semi-autonomous parastatal, Kenya Wildlife Service (KWS) could raise and manage its own funds, hire its own staff and run its operations independently of the Ministry of Tourism and Wildlife, and hence, it had the incentives that its precursor (WMCD) lacked. During the first two years of operation, KWS drew up a new policy framework and development program (also known as the Zebra Book) for the period 1991 to 1996 (Honey, 1999). Through this framework, Community Wildlife Service (CWS) was created to forge co-management initiatives or partnerships with communities outside the parks and reserves and hence enable them to derive direct cash benefits from the presence of wildlife in their land. By 1999, KWS had implemented such projects in the wildlife dispersal areas of Amboseli-Tsavo National Parks, South Coast and Laikipia-Samburu region. From the perspective of Kenyan conservationists these projects are considered as a major breakthrough in wildlife management since they have contributed towards increased wildlife populations and reduction of human-wildlife conflicts.

The foregoing discussion supports the premise that political framework and government policies are an important subset of the conditions determining the application of the comanagement approach in a given region or country. However, even with a favourable policy in Kenya, the adoption of co-management has not been widespread. Moreover, the question remains as to whether this approach has been successful in reconciling the conflicting interests of the diverse stakeholders involved in the conservation and management of wildlife. In Sections 3 and 4 these two shortcomings that concern the implementation of the co-management approach in Kenya are discussed in detail.

\section{Extent of Adoption of Co-management in Kenya}

A country survey carried out by Mburu (2002) showed that adoption of management partnerships in Kenya is dependent on wildlife management policy, institutional capacity to co-manage wildlife, land tenure conditions and access to wildlife resources. As far as 
wildlife policy is concerned it is evident that KWS, as the national custodian of wildlife, is only able to forge partnerships in areas where the current policy allows its direct involvement in conservation issues. As such, in the dispersal areas of the protected areas where it is not directly involved with wildlife management, communities can organise themselves into conservation groups without entering into any negotiations with KWS. Such community-based conservation projects are implemented under the authority of the respective County Councils and KWS's role is reduced to seasonal provision of security ${ }^{3}$ (see Table 1). Thus, due to a weak policy that denies KWS full control and management rights to all wildlife resources in the country, though it owns them, it has not been possible to adopt co-management in all wildlife dispersal areas (Poole and Leakey, 1996). This implies that the claim that the failure to grant local communities property rights and nonconsumptive user rights over wildlife resources limits local communities' participation in conservation initiatives (Honey, 1999; Norton-Griffiths, 2000) may not be playing a relatively important role in the adoption of co-management as it is the case with the wildlife conservation policy and its provisions.

In Kenya, adoption of co-management is favoured by owning titles to land. For instance, the Golini-Mwaluganje co-managed project in Coastal Province did not start off until the community members had acquired title deeds to their land (Kiiru, 1995), a process that was mainly driven by the relatively high incidences of human-wildlife conflicts. However, there are many dispersal areas of Kenyan protected areas where local communities fail to benefit from co-management due to lack of claim to land ownership since the relatively low level of human wildlife conflicts does not attract the attention of conservationists and government as was the case with Golini-Mwaluganje. This lack of land ownership weakens the bargaining position of such communities, making it difficult for them to seek the option of comanagement. In general, local communities with group titles to land have a relatively higher access to wildlife resources than private landowners with smaller units that fail to provide suitable habitats. Thus districts with group ranches, such as Kajiado and Laikipia, have more wildlife partnership activities than other areas. The land subdivision policy can therefore be regarded as an anti-conservation policy that create perverse incentives for the formation of organizations such as wildlife associations which would enter into partnerships with KWS

\footnotetext{
${ }^{3}$ The county councils have also their own security arrangements. However, they are required to call for the assistance of KWS in situations that are difficult for them to handle and particularly if decisions to eliminate certain rogue wildlife have to be made and executed.
} 
for the purpose of ensuring that benefits flow to the communities and losses to wildlife resources are reduced.

Table 1: Co-management wildlife projects in Kenya: viewed from the perspective of KWS

\begin{tabular}{|c|c|c|c|c|}
\hline Project & Role of KWS & $\begin{array}{c}\text { Co-managed } \\
\text { stages of project } \\
\text { cycle }\end{array}$ & $\begin{array}{l}\text { Co-managed } \\
\text { activities }\end{array}$ & $\begin{array}{c}\text { Overall type of } \\
\text { co-management }{ }^{\text {a }}\end{array}$ \\
\hline $\begin{array}{l}\text { 1) Golini- } \\
\text { Mwaluganje of } \\
\text { Taita-Taveta/South } \\
\text { Coast }\end{array}$ & $\begin{array}{l}\text { Provides security } \\
\text { and involved in } \\
\text { all decision- } \\
\text { making activities }\end{array}$ & All stages & All activities & Co-operative \\
\hline $\begin{array}{l}\text { 2) Lualenyi, Oza } \\
\text { and Mramba in } \\
\text { Taita-Taveta/South } \\
\text { coast }\end{array}$ & $\begin{array}{l}\text { Provides security, } \\
\text { does fencing and } \\
\text { makes key } \\
\text { decisions }\end{array}$ & Planning stage & All activities & Consultative \\
\hline $\begin{array}{l}\text { 3) Laikipia } \\
\text { Wildlife Forum }\end{array}$ & $\begin{array}{l}\text { Assist sometimes } \\
\text { in providing } \\
\text { security and } \\
\text { making some } \\
\text { decisions }\end{array}$ & $\begin{array}{c}\text { Implementation } \\
\text { stage }\end{array}$ & $\begin{array}{l}\text { Mainly } \\
\text { security }\end{array}$ & Advisory \\
\hline $\begin{array}{l}\text { 4) Group } \\
\text { Community } \\
\text { projects in } \\
\text { Laikipia/Samburu }\end{array}$ & $\begin{array}{c}\text { Provides security } \\
\text { (sometimes) }\end{array}$ & $\begin{array}{c}\text { Implementation } \\
\text { stage }\end{array}$ & Security only & $\begin{array}{c}- \\
\text { (KWS has no } \\
\text { management } \\
\text { rights) }\end{array}$ \\
\hline $\begin{array}{l}\text { 5) Group } \\
\text { Community } \\
\text { projects in Maasai } \\
\text { Mara }\end{array}$ & $\begin{array}{c}\text { Provides security } \\
\text { (sometimes) }\end{array}$ & $\begin{array}{c}\text { Implementation } \\
\text { stage }\end{array}$ & Security only & $\begin{array}{c}- \\
\text { (KWS has no } \\
\text { management } \\
\text { rights) }\end{array}$ \\
\hline $\begin{array}{l}\text { 6) Kimana, } \\
\text { Selengei, } \\
\text { Mbirikani and } \\
\text { Lorarashi in } \\
\text { greater Amboseli }\end{array}$ & $\begin{array}{l}\text { Provides security, } \\
\text { assists in fence } \\
\text { maintenance, } \\
\text { gives advice when } \\
\text { consulted }\end{array}$ & All stages & All activities & Delegated \\
\hline
\end{tabular}


${ }^{a}$ Since the wildlife projects were not studied in detail, only a general classification of co-management can be given at this stage. It is envisaged that different management tasks will have different kinds of comanagement arrangements.

Mburu, 2002

As has been pointed out by Norton-Griffiths (1997), this disincentive has greatly contributed to relatively higher wildlife losses in districts where land has been subdivided and is privately owned by individuals and where it has been difficult to organize local communities to form wildlife associations or user groups.

Closely related to land tenure and access of wildlife resources is the capacity for the local community to organize themselves into a formidable stakeholder group that can negotiate partnership conditions with KWS and ensure effective local participation of landowners. As Mburu et al. (2003) document, local communities in group ranches have a relatively high capacity for self-organization and access to social capital at both household and community levels, which, because it reduces the effects of heterogeneity, enhances their potential for participation in co-management. Moreover, such groups of landowners have the incentive to lease the co-managed area (e.g. a sanctuary) to tour operators, a strategy that results in efficient management arrangements and which does not only reduce transaction costs borne by landowners but also increases their cash benefits. Having the institutional capacity to comanage wildlife with KWS is therefore an important criteria which ought be considered when determining community groups that can successfully adopt co-management. In essence, without such organized groups co-management may not emerge and thus this factor is as important as the provision of a favorable policy framework.

\section{Rating the Success of Wildlife Co-management in Kenya}

Since the partnership approach or collaborative management seeks to create negotiated agreements between the state and the local communities (other stakeholders may be included), it has been recognised in Kenya as a promising approach that offers a possibility to overcome conflicting interests over wildlife exploitation. However, achieving successful partnership is confronted with many challenges, which may eventually hinder the approach from becoming widespread. In this section, the criteria for assessing the success of comanagement are developed and drawing on results of a number of case studies, the situation in Kenya is evaluated. 


\subsection{Considerations of Criteria for Evaluating Successful Co-management}

Within the context of sustainable development (WCED, report $1987^{4}$ ) and Convention on Biological Diversity (CBD), three broad criteria i.e., economic, ecological, and social (socio-cultural), can be used to evaluate success of co-management in developing countries. However, considerations of success in a short-term perspective will entail further elaboration of these criteria. As Sen and Nielsen (1996: 409) urge, evaluation of comanagement does not necessarily entail quantification of these three components of sustainable development, but assessing whether co-management has positive or negative effects on them. The most common evaluative criteria that can be applied practically are: efficiency, equity and sustainability (Hanna, 1995; IFM-ICLARM, 2001).

Efficiency of co-management can generally be considered in terms of cost-effectiveness where the lowest costs to achieve a particular or stated level of benefits is determined (see, for example, Kuperan et al., 1998). However, there are also situations where flows of both costs and benefits have to be considered (see, for example, Norton-Griffiths, 1996; Barnes et al., 2002; Mburu and Birner, 2002) in order to identify the level of conservation benefits that is efficient (allocative efficiency). The third aspect of efficiency is organisational efficiency (Mburu and Birner, 2002). This latter aspect involves comparison of benefits and costs in order to identify the organisational structure of co-management that would make it possible to achieve certain objectives, for example, maximum net benefits from conservation. It is therefore closely related to allocative efficiency. An important question in this case is as what kinds of characteristics or conditions (e.g. leasing conservation area to tourism operators) make some co-management arrangements more efficient than others both in terms of allocative and organisational efficiency. More, it is important to consider whether transaction costs (costs of participation) play any important role in influencing efficiency of co-management.

Equity refers to fairness to all stakeholders in co-management arrangements or how the outcomes of the management arrangements affect the local communities in terms of race, ethnicity, class and gender (Hanna, 1995: 26; IFM-ICLARM, 2001: 2). It has four main

\footnotetext{
${ }^{4}$ WCED Report (1987) (also called BRUNDTLAND Report) defines sustainable development as development which meets the needs of the present without compromising the ability of future generations to meet their own needs.
} 
components which are, however, not addressed in detail in this paper. These are: representation, process clarity, compatible expectations and distributive effects.

Sustainability in the context of the co-management can be divided into three components: stewardship, resilience and governance. Stewardship is defined as the tendency for resource users to maintain productivity and ecological characteristics of the resource (Sen and Nielsen, 1996: 409). In evaluating the management process in fisheries, Hanna (1995: 2627) identifies three components of stewardship: time horizons, monitoring and enforcement. If resource stewardship is to be enhanced, management should contain incentives to lengthen the time horizon beyond the short term, have adequate and practical systems devised to monitor ecological conditions and human behaviour, and lead to regulations that promote compliance and permit cost-effective enforcement. Resilience is the ability of the co-management systems to absorb and deal with changes and shocks (Nielsen et al., 1998: 16). The co-management process is expected to have rules that are flexible enough to respond quickly to changing conditions and at the same time be able to adapt to both changes in the structure of the industry and changes in the market. Governance is mainly measured in terms of the level of rule compliance. Other measures may include overall reduction in conflict, existence of an effective conflict mechanism, and existence of practical and implementable enforcement procedures.

\subsubsection{Efficiency of the Co-management Approach in Kenya}

The first and most important challenge of co-management in Kenya has been the struggle to create financial incentives that could continually motivate local communities to participate in conservation activities (Watson, 1999). Mburu and Birner (2002) analysis of costs and benefits of co-management initiatives in the dispersal areas of Amboseli National Park and Shimba Hills National Reserve provide useful insights into this aspect. In their financial analysis, local communities' costs arising from contributions in terms of land, time and effort, and cash were discounted and compared with discounted revenue from the tourism activities. Their results showed that none of the three partnership projects in the analysis could be considered profitable from the local communities' perspective. Even under conditions where local communities have leased conservation land to tourism business operators, wildlife does not earn enough revenue to offset costs arising from different streams such as the opportunity costs of land that is set aside for wildlife conservation; costs of installation and maintenance of infra-structure, such as fences, roads, offices, houses for 
wildlife wardens, etc. and maintenance of wildlife; costs arising from destruction to structures, losses of human life, damages to crop and livestock production by wild animals, and the costs incurred to prevent such damages; direct management costs which include recurrent costs from reception of tourists, office work, stationery; and transactions costs arising from the stakeholders' participation (see also Norton-Griffiths, 1996; Emerton, 2001). It therefore seems likely that the partnership projects, whose costs of establishment were mainly subsidized by the state agencies and NGOs, may not continue to operate without assistance from outside. Thus creation of co-management approaches that are not dependent on external funding is yet to be realized in the country. Coupled to the financial incentives aspect is the question as to who bears relatively the bigger proportion of management costs (Meinzen-Dick and Knox, 2001). Mburu (2002) showed that the comanagement approach in Kenya has implied a shift in who bears the costs of wildlife conservation and management, from state agencies to local users or landowners, who particularly shoulder the burden of operational production costs of the projects.

The analysis of different categories of costs of wildlife co-management by Mburu et al. (2003) indicated that in situations or conditions where production costs play an overwhelming major role, transaction costs arising from information acquisition activities, negotiation and operation activities of collaborative management are not a major factor influencing the efficiency of co-management governance structures. However, since it is the local communities who bear these transaction costs, it would be expected that with more devolution of wildlife management to well-organized and competent groups and adoption of co-management, the state and conservation NGOs could save some of their conservation expenditure at the expense of the landowners.

\subsubsection{Distributive and Representational Aspects of Co-management}

Distributional aspects of power and project benefits can be regarded as the second major challenge that may hinder the success of the co-management approach in Kenya. Drawing on co-management examples from Kenya and several other African countries, van den Breemer and Venema (1999) argue that one major condition for the approach to be effective is fair distribution of political power (among the stakeholders) and particularly in the decision-making arrangements in order for stakeholders to be socially recognized and have control during enforcement of rules or agreements. Mburu's (2002) analysis of participation in Kimana and Golini-Mwaluganje partnership projects also showed that co-management 
may not be implemented successfully in conditions where the local communities are under represented in the management boards; their views and desires are disregarded by other stakeholders; management boards lack transparency in their activities; and decision-making process is hijacked by some of the stakeholder groups. Such unfair distribution of power could lead to mistrust of stakeholders and act as a disincentive for the participation of the local communities. According to Hanna (1995) such problems are normally related to the way the local communities are involved during the initial phases of the co-management process and particularly the negotiations. If, for example, the local communities fail to be fully incorporated into the co-management process at the ex ante phase, they are likely, at the ex post phase, to become suspicious of the importance of co-management arrangements leading to non-compliance with the implementation of some activities of the initial contract. This kind of behaviour can result in both local communities and other stakeholder groups incurring considerable production and transaction costs at the ex post phase, as has been empirically investigated by Mburu et al. (2003). But participation in co-management initiatives in Kenya has also been hindered by the heterogeneity of local communities, which is a key factor for facilitating collection action (Baland and Platteau, 1996; Ostrom, 1999). Except in group ranches which are mostly occupied by Maasai and Samburu ${ }^{5}$ ethnic groups (see discussion in Section 3), most of other areas of strategic importance as far as conservation of wildlife is concerned are occupied by landowners who are relatively heterogeneous in terms of culture, social background (ethnic, race, religion, etc.) and economic interests. While it is possible to deal with the problem of heterogeneity by designing appropriate institutions (Varughese and Ostrom, 2001), such options have not been pursued within the Kenyan projects.

\subsubsection{Stewardship, Resilience and Governance of Co-management}

As reported by Norton-Grifitths (2000) and Mburu (2002), one important positive result of KWS forging partnerships with local communities has been the improvement of the condition of the wildlife resource. For instance, Mburu (2002) reports that after adopting comanagement in the dispersal areas of Shimba Hills National Reserve the elephant population in Golini-Mwaluganje grew to the extent that it went beyond the area's carrying capacity and thus translocations to other protected areas had to be conducted. In Laikipia District

\footnotetext{
${ }^{5}$ Maasai and Samburu are closely related ethnic groups that have a similar language, are semi-nomadic pastoralists and have a common culture and traditions. Though they do not live in the same area, they occupy similar agro-ecological zones in the country.
} 
where Laikipia wildlife forum (LWF) has been in partnership with KWS since 1994, elephant numbers in local communities' land have also increased tremendously, prompting KWS to conduct several translocations to Meru National Park. As Gachigiri (2002) reports, more than 2,500 elephants in this area co-existed with livestock by the year 2002, after leaving the surrounding protected areas for better habitats outside. The wildlife count by the Department of Resources Surveys and Remote Sensing (DRSRS) in 1997 also shows that management partnerships improves the level of stewardship and contributes towards resource improvement. Notably, the count showed that between 1994 and 1997 wildlife numbers had either remained unchanged or increased in areas with management partnerships while in other areas losses over the same period were above thirty percent (Norton-Griffiths, 1997). In areas were numbers have increased, wildlife animals, and particularly elephants, have become friendlier to human beings since their existence in the dispersal is not under much threat. This improvement on the nature and number of wildlife has been a great incentive for conservation state agencies and NGOs to continue participating and spending their limited resources in the co-management arrangements. With increased level of stewardship the local communities have, as a result of being involved in management partnerships, gained incentives to lengthen the time of their participation in wildlife comanagement and tourism activities beyond the short term. For example, empirical data collected in Golini-Mwaluganje showed that $74 \%$ of the sample landowners preferred to continue investing in the wildlife conservation even in the long term (Mburu, 2002b).

An important impact of the partnerships, which is also related to the issue of stewardship in wildlife management, is the change of attitude and perception of the landowners towards proconservation stakeholders and wildlife resources. Before the sanctuaries were created, the relationship between KWS and landowners had deteriorated to the extent that the latter had developed a tendency to kill wildlife secretly rather than reporting rogue animals and damages to the former as required by the law. However, with the presence of the partnership arrangements, the landowners have developed a positive altitude towards wildlife animals and have stopped killing them indiscriminately. Nevertheless, due to the unresolved problem of human-wildlife conflicts and the thorny issue of property rights allocation (Norton-Grifitths, 2000) landowners still refer to the wildlife animals as "KWS animals". Moreover, the local communities' main interest has remained unchanged: still want to cultivate their land and do not desire to keep wildlife animals as an alternative (see Section 4.2.3). 
Whether or not the co-management arrangements in Kenya are flexible enough to absorb shocks and deal with changes (e.g. in markets, organisational aspects, etc.) depends mainly on landowners' organizational capacity and the type of management arrangements adopted in different regions. With a 'delegated' type of co-management e.g. in Kimana (see Table 1), the landowners are able to adapt to changing conditions easily. For example, the Kimana landowners were able to reach a decision to lease their conservation area to a tour operator after failing to cope with the marketing burden which was bringing their revenues down. The landowners of Golini-Mwaluganje, on the other hand, had a 'co-operative' type of arrangement, which means that their decisions have to be approved by a conservationistsdominated board in order to be implemented. Landowners who are not well organized are also more predisposed to outside influence, particularly from local politicians. Such external influence also adversely affects how the management board reacts to changing conditions and therefore the success of the partnerships.

The levels of compliance with rules and the handling of conflicts within the conservation areas can be used to gauge how effective the governance of the wildlife resource under comanagement is. However, analysis of compliance with rules in many of the areas where comanagement has been adopted in Kenya are rare. It is therefore difficult to comment whether with the adoption of co-management governance of wildlife resources in the dispersal are has been improved or otherwise.

\subsection{Other Challenges Faced with Implementation of Co-management in Kenya}

\subsubsection{Losses of Biodiversity and Landowners' Sites of Socio-cultural Values}

There are no empirical studies done in areas where the co-management approach has been adopted that can be relied on in assessing whether the increase of wildlife numbers, and particularly elephants, has had adverse effects on other forms of biodiversity. Although Mburu and Birner (2002) did not incorporate the costs of such degradation effects in their economic analysis, they report that the increased number of wildlife has resulted in losses of other kinds of biodiversity. This has particularly been experienced in the dispersal areas of Shimba Hills National Reserve where the considerable high population of elephants have

\footnotetext{
${ }^{6}$ In 'delegated co-management' the government hands over authority to make decisions to user groups who are responsible for informing government of these decisions. In 'cooperative co-management' the government and user groups cooperate together as equal partners in decision making. The latter is viewed as the idealised type of co-management.
} 
destroyed a number of endangered trees' and bushes' species in and around Mwaluganje Forest Reserve. In this same region, the landowners have also lost their shrine areas or $\mathrm{Kaya}^{7}$ forests, which have been local communities' sites of socio-cultural values for many years. Mburu (2002b) also documents that due the high density of wildlife in Kimana Sanctuary, the beautiful canopies of acacia trees, including important species such as Acacia xanthoploea and A. abyssinica, have greatly been degraded. Such environmental losses to the society, which can be viewed as negative external costs of wildlife management, cannot however be underrated when adopting and implementing the co-management approach.

\subsubsection{Inbreeding and Hindering Free Movement of Big Mammals}

Due to the fencing off (using electric fences) of the areas designated for wildlife conservation in order to separate them from the farms and communities' dwelling areas, the free movement of the big mammals has been restricted. Such a fencing strategy has, as expected, reduced the level of human-wildlife conflicts but has on the hand decreased the size of the grazing area that the elephants used to enjoy, forcing them to cloud in small, enclosed areas. In Golini-Mwaluganje sanctuary, for example, Kiiru (1995) reported that although the elephants could move freely between the sanctuary and Shimba Hills National Reserve, they could no longer reach other grazing areas bordering the sanctuary (such as Tsavo East National Park) as they used to before the creation of the co-management projects. This lack of free movement has resulted in the inbreeding of the elephants and a rapid increase of their population in the sanctuary. For instance, during the 1995 aerial census it was estimated that the density of elephant population in the sanctuary was about 2 elephants per $\mathrm{km}^{2}$ (Kiiru, 1995). But within a span of 5 years this population density had risen tremendously to about 7 elephants per $\mathrm{km}^{2}$ while that of adjacent Shimba Hills National Reserve stands at about 3 elephants per $\mathrm{km}^{2}$ (Mburu, 2002). However, there are no studies done in this area to indicate the negative effects that this high population of wildlife coud have on the environment and the society. Thus, it would be of paramount importance to assess the implications that inbreeding of wildlife and their lack of free movement could have on the future of the co-management projects.

\footnotetext{
${ }^{7}$ The Kaya used to be the homesteads of the Mijikenda ethnic groups. Their location in dense forests and hilltops was meant for avoiding attacks from raiding tribes. Today they are treated as shrines, which are of cultural and religious significance.
} 
Mburu (2002) also reports another problem associated with the fencing strategy in comanagement projects. He found that in the dispersal areas of Amboseli National Park fencing off the sanctuary area from important gazing areas and watering points of elephants has not only hindered free movement of the animals but has also resulted in diversion of crop destruction to new areas which never used to experience this menace before creation of the tourism projects. This negative impact arises since after creating the co-management projectss the wildlife density and diversity has increased to the extent that it is difficult to contain the animals all the time in the fenced areas. As a result, crop destruction costs are also borne by landowners who are not living the project areas and therefore not involved in the co-management. This also demonstrates how complex investing in wildlife comanagement can be for the participating stakeholders and how high levels of uncertainty with wildlife could lead to unanticipated production costs to the society.

\subsubsection{Altering the Economic Interests of the Local Communities}

In analyzing the livelihood strategies of the local communities live together with wildlife, Bourn and Blench (1999) found that pastoralism, and particularly the nomadic pastoralism of the Maasai and their indigenous knowledge, are compatible with wildlife conservation. However, the analysis of interests by Mburu (2002b) showed that these communities are still not comfortable with the presence of wildlife in their land. Even after introducing partnerships or co-management, the landowners do not view wildlife conservation as a sustainable way of earning a household income and thus the objective of making wildlifebased economic activities become the communities' 'second cattle' (Western, 1994) is still far from being realised. The communities' greatest desire has remained to have all the wildlife kept away or be fenced off of their land. The presence of wildlife is regarded as a threat to the farming activities which many of the landowners dependent on for their livelihood. The wildlife is also considered as a great threat to their security and as a hindrance to the performance of other economic activities. Thus wildlife conservation through co-management has failed to be recognized as a livelihood option by the landowners. This may most likely be emanating from the fact that wildlife co-management is financial viable to the landowners as has been argued in Section 4.1.1.

The desire for communities to have the wildlife fenced off their land may also be emanating from the distribution of the land, and wildlife ownership and management property rights as has been highlighted in Section 4.1.3. Moreover, this desire has been greatly cultivated by 
the savings in guarding costs and losses from crops and livestock that the landowners have received from the fence installed in certain areas. The landowners' main interest is therefore to enhance farming activities in order to make full benefits out of the investments in electrical fencing. This obviously contrasts with the pro-conservation stakeholders' desire of making wildlife conservation and tourism an alternative form of land use to the farming practices of the local communities in order to enhance, through minimization of humanwildlife conflicts and costs, the co-existence of wildlife and humans. To an extent, the landowners' behaviour is also related to their perceptions that the best option for wildlife management in their local areas is to have the KWS play a relatively bigger role even in the event of adopting the co-management approach (Mburu, 2002).

\section{Concluding remarks}

This paper started by looking at the evolution of different strategies of wildlife management in Kenya, and generally in developing countries, in order to examine some of the factors or conditions that lead to emergence and subsequent adoption of the co-management approach. It is clear from the analysis carried out here that co-management has become popular among conservationists and development practitioners due to the shortcomings of both the centralised management and community-based approaches to fulfil the conflicting interests of diverse stakeholder groups. It has been emphasised that the major condition favouring adoption of the co-management approach in a developing country like Kenya is the provision of a favourable policy to the implementing agency and devolution of management roles to organized user groups which have the institutional capacity to co-manage wildlife resources. Other factors that are also important in this respect include land tenure conditions that allow community members to own private land as a group and accessibility to wildlife resources.

Although wildlife co-management in Kenya has been successful in terms of reduction of human-wildlife conflicts and securing increases in wildlife numbers, not all the interests of the stakeholders have been met. The landowners, in particular, have to contend with the fact that there are considerably high production costs and transaction costs involved in the management activities, making the co-management projects financially unprofitable. This may be the main reason why the local communities have not been able to change their economic interests and make wildlife management a major livelihood strategy which could 
also form a substitute for the subsistence farming. Notwithstanding, the reduction of humanwildlife conflicts and hence the increase in crop and livestock produce, and security for human beings can be regarded as key incentives that play an important role in motivating long-term involvement of local communities in the partnerships or co-management projects.

A key challenge facing co-management initiatives in the country is the involvement heterogeneous community groups who lack the capacity to participate effectively. In addition, problems associated with the application of the fencing strategy, for example, increased inbreeding and prevention of free movement of large mammals, increased losses of other forms of plant and animal diversity, etc., will need to be addressed. These problems, including the loss of local communities' socio-cultural wealth, have to be regarded as externalities of the co-management or costs borne by the society which may adversely affect the success of this approach in the future. Thus, one important policy implication is that these negative impacts of the co-management approach and its failure to produce financial incentives will have to be dealt with by conservationists and policy makers in Kenya before this strategy of managing wildlife resources in the dispersal areas of protected areas becomes widespread in the country.

\section{References}

Baland J-M. and Platteau J-P., 1996. Halting degradation of natural resources: Is there a role for rural communities? Clarendon Press, Oxford, UK.

Barnes J. I., MacGregor J. and Weaver L. C., 2002. Economic Analysis of Community Wildlife Use Initiatives in Namibia. In: World Development, 30, No. 4, 667-681. Elsevier Science Ltd.

Barrow E. and Murphree M., 2001. Community Conservation from Concept to Practice. In: Hulme D. and Murphree M. (eds.), 208-226 (2001). African Wildlife and Livelihoods: The Promise and Performance of Community Conservation. James Curry Limited, Oxford, UK.

Barrow E., Gichohi H. and Infield M., 2001. The Evolution of Community Conservation Policy and Practice in East Africa. In: Hulme D. and Murphree M. (eds.), 59-73 (2001). African Wildlife and Livelihoods: The Promise and Performance of Community Conservation. James Curry Limited, Oxford, UK.

Borrini-Feyerabend G., 1996. Collaborative Management of Protected Areas: Tailoring the Approach to the Context. Issues in Social policy, IUCN, Gland, Switzerland.

Borrini-Feyerabend G., Farvar T. M., Nguinguiri C. J., and Ndangang A. V., 2000. Comanagement of Natural Resources: Organising, Negotiating and Learning-by-Doing. GTZ and IUCN, Kasparek Verlag, Heidelberg, Germany. 
Bourn D. and Blench R., 1999. Can Livestock and Wildlife Co-exist? An Interdisciplinary Approach. Overseas Development Institute, London, UK.

Emerton L., 2001. The Nature of Benefits and Benefits of Nature: Why Wildlife Conservation has not Economically Benefited Communities in Africa. In Hulme D. and Murphree M. (eds.), 208-226 (2001). African Wildlife and Livelihoods: The Promise and Performance of Community Conservation. James Curry Limited, Oxford, UK.

Gachigiri B., 2003. KWS to Pay Ksh. 23 Million in Compensation. East African Standard, 02.03.03, Nairobi, Kenya (also http://www.eastandard.net/national, accessed in March 2003).

Hanna S., 1995. User Participation and Fishery Management Performance within the Pacific Fishery Management Council. In: Ocean and Coastal Management, 28, Nos. 1-3, 23-44, Elsevier Science Ltd.

Hilhorst T. and Aarnink A., 1999. Co-managing the Commons: Setting stage in Mali and Zambia. Bulletins of the Royal Tropical Institute, Amsterdam, The Netherlands.

Honey M., 1999. Ecotourism and Sustainable Development: Who Owns Paradise? Island Press, Washington D.C.

IFM-ICLARM, 2001. Co-management Project Research Framework for Phase II. Institute for Fisheries Management and Coastal Community Development (IFM) and ICLARM. (http://www.co-management.org, accessed in July 2002).

IIED, 1994. Whose Eden? An Overview of Community Approaches to Wildlife Management. A Report to the Overseas Development Administration of the British Government. International Institute for Environment and Development, Nottingham, UK.

Kiiru W., 1995. Human-Elephant Interaction around Shimba Hills National Reserve, Kenya. M.sc Thesis in Tropical Resource Ecology, University of Zimbabwe, Harare, Zimbabwe.

Kiss A., 1999. A Strategic Framework for Conservation of Biological Diversity in SubSaharan Africa. World Bank, Washington DC, USA.

Kock A. R., 1995. Wildlife Utilisation: Use it or Lose it - a Kenyan Perspective. In: Biodiversity and Conservation 4, 241-256 (1995). Chapman and Hall.

Kuperan K., Abdullah N. M. R., Pomeroy R. S., Genio E. and Salamanca A., 1998. Measuring Transaction Costs of Fisheries Co-management, Paper Presented at the 7th Biennial Conference of the International Association for the Study of Common Property, Vancouver (http://www.indiana.edu/ iascp/Drafts/kuperan.pdf., accessed in May 2000).

Leach M., Mearns R. and Scoones I., 1999. Environmental Entitlements: Dynamics and Institutions in Community-based Natural Resource Management. In: World development 27, No. 2, 225-247, Elsevier Science Ltd.

Lutz E. and Caldecott J., 1996. Introduction. In: Lutz E. and Caldecott J. (eds.), 1-4 (1996). Decentralization and Biodiversity Conservation. The World Bank, Washington, D.C.

Mburu J., Birner R. and Zeller M., 2003. Relative importance and determinants of landowners' transaction costs in collaborative wildlife management in Kenya: An empirical analysis. In: Ecological Economics: transdisciplinary journal of the International Society for Ecological Economics, 45 No. 1, 59-73. Elsevier Science ltd.

Mburu J., 2002. Collaborative Management of Wildlife in Kenya: An Empirical Analysis of Stakeholders' Participation, Costs and Incentives. Socio-economic Studies on Rural Development Vol. 130. Wissenschaftsverlag Vauk Kiel KG, Kiel, Germany. 
Mburu J., 2002b. Challenges of Partnerships in Tourism Projects: The Case of Kimana and Golini-Mwaluganje Sanctuaries in Kenya. Paper presented at the Seminar on Eco-tourism and Nature Parks in East and Southern Africa, November 12, 2002, African Studies Centre, Leiden, The Netherlands.

Mburu J. and Birner R., 2002. Analyzing the Efficiency of Collaborative Wildlife Management: The Case of two Community Sanctuaries in Kenya. In: International Journal of Organization Theory and Behavior 5, No. 3 and 4, 259-297, Marcel Dekker, Inc.

Meinzen-Dick R. and Knox A., 2001. Collective Action, Property Rights, and Devolution of Natural Resource Management: A Conceptual Framework. In: Meinzen-Dick R., Knox A. and Di Gregorio M. (eds.), 41-74 (2001). Collective Action, Property Rights and Devolution of Natural Resource Management - Exchange of Knowledge and Implications for Policy, CAPRi, ICLARM, ZEL/DSE, Eurasburg.

Nielsen J. R., Sen S., Svendrup-Jensen S. and Pomeroy R. S., 1998. Analysis of Fisheries Co-management Arrangements: A Research Framework. Institute of Fisheries Management and Coastal Community Development (IFM) and International Centre for Living Aquatic Resources Management (ICLARM) (www.co-management.org, accessed in January 2000).

Norton-Griffiths M., 1996. Property rights and the marginal wildebeest: An Economic Analysis of Wildlife Conservation Options in Kenya. In Biodiversity and Conservation 5, 1557-1577, Chapman and Hall.

Norton-Griffiths M., 1997. Why Kenyan Conservation is Failing. In: Swara: Vol. 19:6 \& 20:1, 6-8, East African Wildlife Society.

Norton-Griffiths M., 2000. Wildlife losses in Kenya: An analysis of Conservation. In: Natural Resource Modelling, 13, No. 1, 13-34, Texas Tech Press.

Ostrom E., 1999. Self-Governance and Forest Resources. CIFOR Occasional Paper No. 20. Centre for International Forestry Research, Bogor, Indonesia.

Pomeroy R. S., 2001. Devolution and Fisheries Co-management. In: Meinzen-Dick R., Knox A. and M. Di Gregorio (eds.), 111-146 (2001). Collective Action, Property Rights and Devolution of Natural Resource Management- Exchange of Knowledge and Implications for Policy, CAPRi, ICLARM, ZEL/DSE, Eurasburg.

Poole J. H. and Leakey R. E., 1996. Kenyan case study. In: Lutz E. and Caldecott J. (eds.), 54-63 (1996). Decentralization and Biodiversity Conservation. The World Bank, Washington, D.C.

Republic of Kenya, 1975. Sessional Paper No. 3 of 1975: Statement on the Future of Wildlife Management Policy in Kenya, Government Printer, Nairobi.

Sen S. and Nielsen J. R., 1996. Fisheries Co-management: a comparative analysis. In: Marine Policy, 20, No. 5, 405-418, Elsevier Science Ltd.

Sindiga I., 1999. Alternative Tourism and Sustainable Development in Kenya. In: The Journal of Sustainable Tourism, 7, No. 2, 108-127, Channel View Publications.

Songorwa A.N., 1999. Community-based Wildlife Management (CWM) in Tanzania: Are the Communities Interested? In: World development 27, No. 12, 2061-2079. Elsevier Science Ltd.

Van den Breemer H. and Venema B., 1999. From Command to Contract in Natural Resource Management in Africa. In: Venema B. and van den Breemer H. (eds.), 305-342 
(1999). Towards Negotiated Co-management of Natural Resources in Africa, Lit Verlag, Muenster, Germany.

Varughese G. and Ostrom E., 2001. The Contested Role of Heterogeneity in Collective Action: Some Evidence from Community Forestry in Nepal. In: World development 29, No. 5, 747-765, Elsevier Science Ltd.

Venema B. and van den Breemer H., 1999. Natural Resource Management in Africa: Approaches, Contraints and Opportunities. In: Venema B. and van den Breemer H. (eds.), 118 (1999). Towards Negotiated Co-management of Natural Resources in Africa, Lit Verlag, Muenster, Germany.

Virtanen P., 2003. Local Management of Global Values: Community-Based Wildlife Management in Zimbambwe and Zambia. In Society and Natural Resources 16, 179-190, Taylor and Francis.

Wainwright C. and Wehrmeyer W., 1998. Success in Integrating Conservation and Development? A Study from Zambia. In: World development 26, No. 6, 933-944, Elsevier Science Ltd.

Watson A., 1999. Conservation of Biodiverse Resource Areas (COBRA) Project: Kenya (1992-1998) Summary Report. A Report Prepared for USAID, Nairobi, Nairobi, Kenya.

Western D., 1994. Ecosystem Conservation and rural Development: The Case of Amboseli. In: Western, D., Wright R. M. (eds) and Strum S. C (associate ed.), 15-52 (1994). Natural Connections: Perspectives in Community-based Conservation. Island Press, Washington D.C.

World Commission on Environment and Development (WCED), 1987. Our Common Future. Cambridge University Press, Oxford, UK. 


\section{NOTE DI LAVORO DELLA FONDAZIONE ENI ENRICO MATTEI}

Fondazione Eni Enrico Mattei Working Paper Series

Our Note di Lavoro are available on the Internet at the following addresses: http://www.feem.it/Feem/Pub/Publications/WPapers/default.html

http://www.ssrn.com/link/feem.html

\section{NOTE DI LAVORO PUBLISHED IN 2003}

\begin{tabular}{|c|c|c|}
\hline PRIV & 1.2003 & 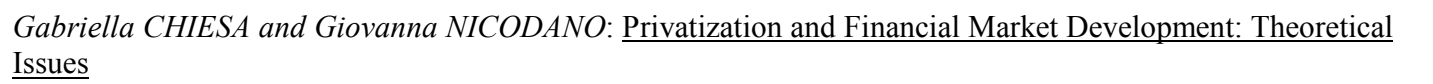 \\
\hline PRIV & 2.2003 & Ibolya SCHINDELE: Theory of Privatization in Eastern Europe: Literature Review \\
\hline PRIV & .2003 & $\begin{array}{l}\text { Wietze LISE, Claudia KEMFERT and Richard S.J. TOL: Strategic Action in the Liberalised German Electricity } \\
\text { Market }\end{array}$ \\
\hline CLIM & 4.2003 & $\begin{array}{l}\text { Laura MARSILIANI and Thomas I. RENSTRÖM: Environmental Policy and Capital Movements: The Role of } \\
\text { Government Commitment }\end{array}$ \\
\hline KNOW & 5.2003 & Reyer GERLAGH: Induced Technological Change under Technological Competition \\
\hline ETA & 6.2003 & Efrem CASTELNUOVO: Squeezing the Interest Rate Smoothing Weight with a Hybrid Expectations Model \\
\hline SIEV & 7.2003 & $\begin{array}{l}\text { Anna ALBERINI, Alberto LONGO, Stefania TONIN, Francesco TROMBETTA and Margherita TURVANI: The } \\
\text { Role of Liability, Regulation and Economic Incentives in Brownfield Remediation and Redevelopment: } \\
\text { Evidence from Surveys of Developers }\end{array}$ \\
\hline NRM & 8.2003 & Elissaios PAPYRAKIS and Reyer GERLAGH: Natural Resources: A Blessing or a Curse? \\
\hline CLIM & 2003 & $\begin{array}{l}\text { A. CAPARRÓS, J.-C. PEREAU and T. TAZDAÏT: North-South Climate Change Negotiations: a Sequential Game } \\
\text { with Asymmetric Information }\end{array}$ \\
\hline KNOW & 10.2003 & Giorgio BRUNELLO and Daniele CHECCHI: School Quality and Family Background in Italy \\
\hline CLIM & 11.2003 & $\begin{array}{l}\text { Efrem CASTELNUOVO and Marzio GALEOTTI: Learning By Doing vs Learning By Researching in a Model of } \\
\text { Climate Change Policy Analysis }\end{array}$ \\
\hline KNOW & 12.2003 & $\begin{array}{l}\text { Carole MAIGNAN, Gianmarco OTTAVIANO and Dino PINELLI (eds.): Economic Growth, Innovation, Cultural } \\
\text { Diversity: What are we all talking about? A critical survey of the state-of-the-art }\end{array}$ \\
\hline KNOW & 13.2003 & $\begin{array}{l}\text { Carole MAIGNAN, Gianmarco OTTAVIANO, Dino PINELLI and Francesco RULLANI (lix): Bio-Ecological } \\
\text { Diversity vs. Socio-Economic Diversity. A Comparison of Existing Measures }\end{array}$ \\
\hline KNOW & 14.2003 & $\begin{array}{l}\text { Maddy JANSSENS and Chris STEYAERT (lix): Theories of Diversity within Organisation Studies: Debates and } \\
\text { Future Trajectories }\end{array}$ \\
\hline KNOW & 15.2003 & $\begin{array}{l}\text { Tuzin BAYCAN LEVENT, Enno MASUREL and Peter NIJKAMP (lix): Diversity in Entrepreneurship: Ethnic and } \\
\text { Female Roles in Urban Economic Life }\end{array}$ \\
\hline KNOW & 16.2003 & $\begin{array}{l}\text { Alexandra BITUSIKOVA (lix): Post-Communist City on its Way from Grey to Colourful: The Case Study from } \\
\text { Slovakia }\end{array}$ \\
\hline KNOW & 7.2003 & 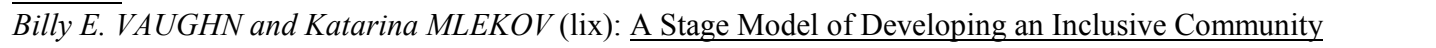 \\
\hline $\begin{array}{l}\text { KNOW } \\
\text { Coalition }\end{array}$ & 18.2003 & Selma van LONDEN and Arie de RUIJTER (lix): Managing Diversity in a Glocalizing World \\
\hline $\begin{array}{l}\text { Theory } \\
\text { Network }\end{array}$ & 19.2003 & Sergio CURRARINI: On the Stability of Hierarchies in Games with Externalities \\
\hline PRIV & 20.2003 & Giacomo CALZOLARI and $A$ \\
\hline PRIV & 21.2003 & $\begin{array}{l}\text { Claudio MEZZETTI (lx): Auction Design with Interdependent Valuations: The Generalized Revelation } \\
\text { Principle, Efficiency, Full Surplus Extraction and Information Acquisition }\end{array}$ \\
\hline PRIV & 22.2003 & $\begin{array}{l}\text { Marco LiCalzi and Alessandro PAVAN (lx): Tilting the Supply Schedule to Enhance Competition in Uniform- } \\
\text { Price Auctions }\end{array}$ \\
\hline PRIV & 23.2003 & David ETTINGER (1x): Bidding among Friends and Enemies \\
\hline PRIV & 24.2003 & Hannu VARTIAINEN (lx): Auction Design without Commitment \\
\hline PRIV & 25.2003 & $\begin{array}{l}\text { Matti KELOHARJU, Kjell G. NYBORG and Kristian RYDQVIST (lx): Strategic Behavior and Underpricing in } \\
\text { Uniform Price Auctions: Evidence from Finnish Treasury Auctions }\end{array}$ \\
\hline PRIV & 5.2003 & Christine A. PARLOUR and Uday RAJAN (1x): Ratic \\
\hline PRIV & 27.2003 & Kjell G. NYBORG and Ilya A. STREBULAEV (lx): Multiple Unit Auctions and Short Squeezes \\
\hline PRIV & 28.2003 & $\begin{array}{l}\text { Anders LUNANDER and Jan-Eric NILSSON (lx): Taking the Lab to the Field: Experimental Tests of Alternative } \\
\text { Mechanisms to Procure Multiple Contracts }\end{array}$ \\
\hline PRIV & 29.2003 & $\overline{\text { TangaMcDANIEL and Karsten NEUHOFF (lx): Use of Long-term Auctions for Network Investment }}$ \\
\hline PRIV & 30.2003 & Emiel MAASLAND and Sander ONDERSTAL (1x): Auctions with Financial Externalities \\
\hline ETA & 31.2003 & $\begin{array}{l}\text { Michael FINUS and Bianca RUNDSHAGEN: A Non-cooperative Foundation of Core-Stability in Positive } \\
\text { Externality NTU-Coalition Games }\end{array}$ \\
\hline KNOW & 32.2003 & ion and Irreversible Investments under Uncertainty \\
\hline PRIV & 33.2003 & Philippe QUIRION: Relative Quotas: Correct Answer to Uncertainty or Case of Regulatory Capture? \\
\hline KNOW & 34.2003 & $\begin{array}{l}\text { Giuseppe MEDA, Claudio PIGA and Donald SIEGEL: On the Relationship between R\&D and Productivity: A } \\
\text { Treatment Effect Analysis }\end{array}$ \\
\hline ETA & 35.2003 & $\begin{array}{l}\text { Alessandra DEL BOCA, Marzio GALEOTTI and Paola ROTA: Non-convexities in the Adjustment of Different } \\
\text { Capital Inputs: A Firm-level Investigation }\end{array}$ \\
\hline
\end{tabular}




\begin{tabular}{|c|c|c|}
\hline GG & 36.2003 & Matthieu GLACHANT: Voluntary Agreements under Endogenous Legislative Threats \\
\hline PRIV & 37.2003 & $\begin{array}{l}\text { Narjess BOUBAKRI, Jean-Claude COSSET and Omrane GUEDHAMI: Postprivatization Corporate } \\
\text { Governance: the Role of Ownership Structure and Investor Protection }\end{array}$ \\
\hline CLIM & 38.2003 & Rolf GOLOMBEK and Michael HOEL: Climate Policy under Technology Spillovers \\
\hline KNOW & 39.2003 & Slim BEN YOUSSEF: Transboundary Pollution, R\&D Spillovers and International Trade \\
\hline CTN & 40.2003 & Carlo CARRARO and Carmen MARCHIORI: Endogenous Strategic Issue Linkage in International Negotiations \\
\hline KNOW & 41.2003 & Sonia OREFFICE: Abortion and Female Power in the Household: Evidence from Labor Supply \\
\hline KNOW & 42.2003 & $\begin{array}{l}\text { Timo GOESCHL and Timothy SWANSON: On Biology and Technology: The Economics of Managing } \\
\text { Biotechnologies }\end{array}$ \\
\hline ETA & 43.2003 & $\begin{array}{l}\text { Giorgio BUSETTI and Matteo MANERA: STAR-GARCH Models for Stock Market Interactions in the Pacific } \\
\text { Basin Region, Japan and US }\end{array}$ \\
\hline CLIM & 44.2003 & $\begin{array}{l}\text { Katrin MILLOCK and Céline NAUGES: The French Tax on Air Pollution: Some Preliminary Results on its } \\
\text { Effectiveness }\end{array}$ \\
\hline PRIV & 45.2003 & $\overline{\text { Bernardo BORTOLOTTI and Paolo PINOTTI: The Political Economy of Privatization }}$ \\
\hline SIEV & 46.2003 & $\begin{array}{l}\text { Elbert DIJKGRAAF and Herman R.J. VOLLEBERGH: Burn or Bury? A Social Cost Comparison of Final Waste } \\
\text { Disposal Methods }\end{array}$ \\
\hline ETA & 47.2003 & $\begin{array}{l}\text { Jens HORBACH: Employment and Innovations in the Environmental Sector: Determinants and Econometrical } \\
\text { Results for Germany }\end{array}$ \\
\hline CLIM & 48.2003 & $\begin{array}{l}\text { Lori SNYDER, Nolan MILLER and Robert STAVINS: The Effects of Environmental Regulation on Technology } \\
\text { Diffusion: The Case of Chlorine Manufacturing }\end{array}$ \\
\hline CLIM & 49.2003 & $\begin{array}{l}\text { Lori SNYDER, Robert STAVINS and Alexander F. WAGNER: Private Options to Use Public Goods. Exploiting } \\
\text { Revealed Preferences to Estimate Environmental Benefits }\end{array}$ \\
\hline CTN & 50.2003 & László Á. KÓCZY and Luc LAUWERS (lxi): The Minimal Dominant Set is a Non-Empty Core-Extension \\
\hline CTN & 51.2003 & Matthew O. JACKSON (1xi): Allocation Rules for Network Games \\
\hline CTN & 52.2003 & Ana MAULEON and Vincent VANNETELBOSCH (1xi): Farsightedness and Cautiousness in Coalition Formation \\
\hline CTN & 53.2003 & Fernando VEGA-REDONDO (1xi): Building Up Social Capital in a Changing World: a network approach \\
\hline CTN & 54.2003 & Matthew HAAG and Roger LAGUNOFF (lxi): On the Size and Structure of Group Cooperation \\
\hline CTN & 55.2003 & Taiji FURUSAWA and Hideo KONISHI (lxi): $\underline{\text { Free Trade Networks }}$ \\
\hline CTN & 56.2003 & Halis Murat YILDIZ (1xi): National Versus International Mergers and Trade Liberalization \\
\hline CTN & 57.2003 & $\begin{array}{l}\text { Santiago RUBIO and Alistair ULPH (lxi): An Infinite-Horizon Model of Dynamic Membership of International } \\
\text { Environmental Agreements }\end{array}$ \\
\hline KNOW & 58.2003 & $\begin{array}{l}\text { Carole MAIGNAN, Dino PINELLI and Gianmarco I.P. OTTAVIANO: ICT, Clusters and Regional Cohesion: A } \\
\text { Summary of Theoretical and Empirical Research }\end{array}$ \\
\hline KNOW & 59.2003 & Giorgio BELLETTINI and Gianmarco I.P. OTTAVIANO: Special Interests and Technological Change \\
\hline ETA & 60.2003 & Ronnie SCHÖB: The Double Dividend Hypothesis of Environmental Taxes: A Survey \\
\hline CLIM & 61.2003 & $\begin{array}{l}\text { Michael FINUS, Ekko van IERLAND and Robert DELLINK: Stability of Climate Coalitions in a Cartel } \\
\text { Formation Game }\end{array}$ \\
\hline GG & 62.2003 & $\begin{array}{l}\text { Michael FINUS and Bianca RUNDSHAGEN: } \text { How the Rules of Coalition Formation Affect Stability of } \\
\text { International Environmental Agreements }\end{array}$ \\
\hline SIEV & 63.2003 & Alberto PETRUCCI: Taxing Land Rent in an Open Economy \\
\hline CLIM & 64.2003 & $\begin{array}{l}\text { Joseph E. ALDY, Scott BARRETT and Robert N. STAVINS: Thirteen Plus One: A Comparison of Global Climate } \\
\text { Policy Architectures }\end{array}$ \\
\hline SIEV & 65.2003 & Edi DEFRANCESCO: The Beginning of Organic Fish Farming in Italy \\
\hline SIEV & 66.2003 & Klaus CONRAD: Price Competition and Product Differentiation when Consumers Care for the Environment \\
\hline SIEV & 67.2003 & $\begin{array}{l}\text { Paulo A.L.D. NUNES, Luca ROSSETTO, Arianne DE BLAEIJ: Monetary Value Assessment of Clam Fishing } \\
\text { Management Practices in the Venice Lagoon: Results from a Stated Choice Exercise }\end{array}$ \\
\hline CLIM & 68.2003 & $\begin{array}{l}\text { ZhongXiang ZHANG: Open Trade with the U.S. Without Compromising Canada's Ability to Comply with its } \\
\text { Kyoto Target }\end{array}$ \\
\hline KNOW & 69.2003 & David FRANTZ (lix): Lorenzo Market between Diversity and Mutation \\
\hline KNOW & 70.2003 & Ercole SORI (lix): Mapping Diversity in S \\
\hline KNOW & 71.2003 & Ljiljana DERU SIMIC (lxii): What is Specific about Art/Cultural Projects? \\
\hline KNOW & 72.2003 & $\begin{array}{l}\text { Natalya V. TARANOVA (lxii): The Role of the City in Fostering Intergroup Communication in a Multicultural } \\
\text { Environment: Saint-Petersburg's Case }\end{array}$ \\
\hline KNOW & 73.2003 & $\begin{array}{l}\text { Kristine CRANE (lxii): The City as an Arena for the Expression of Multiple Identities in the Age of } \\
\text { Globalisation and Migration }\end{array}$ \\
\hline KNOW & 74.2003 & Kazuma MATOBA (lxii): Glocal Dialogue- Transformation through Transcultural Communication \\
\hline KNOW & 75.2003 & $\begin{array}{l}\text { Catarina REIS OLIVEIRA (lxii): Immigrants' Entrepreneurial Opportunities: The Case of the Chinese in } \\
\text { Portugal }\end{array}$ \\
\hline KNOW & 76.2003 & Sandra WALLMAN (1xii): The Diversity of Diversity - towards a typology of urban systems \\
\hline KNOW & 77.2003 & Richard PEARCE (lxii): A Biologist's View of Individual Cultural Identity for the Study of Cities \\
\hline KNOW & 78.2003 & $\begin{array}{l}\text { Vincent MERK (lxii): Communication Across Cultures: from Cultural Awareness to Reconciliation of the } \\
\text { Dilemmas }\end{array}$ \\
\hline KNOW & 79.2003 & $\begin{array}{l}\text { Giorgio BELLETTINI, Carlotta BERTI CERONI and Gianmarco I.P.OTTAVIANO: Child Labor and Resistance } \\
\text { to Change }\end{array}$ \\
\hline ETA & 80.2003 & $\begin{array}{l}\text { Michele MORETTO, Paolo M. PANTEGHINI and Carlo SCARPA: Investment Size and Firm's Value under } \\
\text { Profit Sharing Regulation }\end{array}$ \\
\hline
\end{tabular}




\begin{tabular}{|c|c|c|}
\hline IEM & 81.2003 & $\begin{array}{l}\text { Alessandro LANZA, Matteo MANERA and Massimo GIOVANNINI: Oil and Product Dynamics in International } \\
\text { Petroleum Markets }\end{array}$ \\
\hline CLIM & 82.2003 & $\begin{array}{l}\text { Y. Hossein FARZIN and Jinhua ZHAO: Pollution Abatement Investment When Firms Lobby Against } \\
\text { Environmental Regulation }\end{array}$ \\
\hline CLIM & 83.2003 & Giuseppe DI VITA: Is the Discount Rate Relevant in Explaining the Environmental Kuznets Curve? \\
\hline CLIM & 84.2003 & Reyer GERLAGH and Wietze LISE: Induced Technological Change Under Carbon Taxes \\
\hline NRM & 85.2003 & $\begin{array}{l}\text { Rinaldo BRAU, Alessandro LANZA and Francesco PIGLIARU: How Fast are the Tourism Countries Growing? } \\
\text { The cross-country evidence }\end{array}$ \\
\hline KNOW & 86.2003 & $\begin{array}{l}\text { Elena BELLINI, Gianmarco I.P. OTTAVIANO and Dino PINELLI: The ICT Revolution: opportunities and risks } \\
\text { for the Mezzogiorno }\end{array}$ \\
\hline SIEV & 87.2003 & $\begin{array}{l}\text { Lucas BRETSCGHER and Sjak SMULDERS: } \underline{\text { Sustainability and Substitution of Exhaustible Natural Resources. }} \\
\text { How resource prices affect long-term R\&D investments }\end{array}$ \\
\hline CLIM & 88.2003 & $\begin{array}{l}\text { Johan EYCKMANS and Michael FINUS: New Roads to International Environmental Agreements: The Case of } \\
\text { Global Warming }\end{array}$ \\
\hline CLIM & 89.2003 & Marzio GALEOTTI: Economic Development and Environmental Protection \\
\hline CLIM & 90.2003 & Marzio GALEOTTI: Environment and Economic Growth: Is Technical Change the Key to Decoupling? \\
\hline CLIM & 91.2003 & Marzio GALEOTTI and Barbara BUCHNER: Climate Policy and Economic Growth in Developing Countries \\
\hline IEM & 92.2003 & $\begin{array}{l}\text { A. MARKANDYA, A. GOLUB and E. STRUKOVA: The Influence of Climate Change Considerations on Energy } \\
\text { Policy: The Case of Russia }\end{array}$ \\
\hline ETA & 93.2003 & Andrea BELTRATTI: Socially Responsible Investment in General Equilibrium \\
\hline CTN & 94.2003 & Parkash CHANDER: The $\gamma$-Core and Coalition Formation \\
\hline IEM & 95.2003 & $\begin{array}{l}\text { Matteo MANERA and Angelo MARZULLO: Modelling the Load Curve of Aggregate Electricity Consumption } \\
\text { Using Principal Components }\end{array}$ \\
\hline IEM & 96.2003 & $\begin{array}{l}\text { Alessandro LANZA, Matteo MANERA, Margherita GRASSO and Massimo GIOVANNINI: Long-run Models of } \\
\text { Oil Stock Prices }\end{array}$ \\
\hline CTN & 97.2003 & $\begin{array}{l}\text { Steven J. BRAMS, Michael A. JONES, and D. Marc KILGOUR: Forming Stable Coalitions: The Process } \\
\text { Matters }\end{array}$ \\
\hline KNOW & 98.2003 & $\begin{array}{l}\text { John CROWLEY, Marie-Cecile NAVES (lxiii): Anti-Racist Policies in France. From Ideological and Historical } \\
\text { Schemes to Socio-Political Realities }\end{array}$ \\
\hline KNOW & 99.2003 & Richard THOMPSON FORD (lxiii): Cultural Rights and Civic Virtue \\
\hline KNOW & 100.2003 & Alaknanda PATEL (lxiii): Cultural Diversity and Conflict in Multicultural Cities \\
\hline KNOW & 101.2003 & David MAY (lxiii): The Struggle of Becoming Established in a Deprived Inner-City Neighbourhood \\
\hline KNOW & 102.2003 & $\begin{array}{l}\text { Sébastien ARCAND, Danielle JUTEAU, Sirma BILGE, and Francine LEMIRE (lxiii) : Municipal Reform on the } \\
\text { Island of Montreal: Tensions Between Two Majority Groups in a Multicultural City }\end{array}$ \\
\hline CLIM & 103.2003 & Barbara BUCHNER and Carlo CARRARO: China and the Evolution of the Present Climate Regime \\
\hline CLIM & 104.2003 & $\begin{array}{l}\text { Barbara BUCHNER and Carlo CARRARO: } \overline{\text { Emissions Trading Regimes and Incentives to Participate in }} \\
\text { International Climate Agreements }\end{array}$ \\
\hline CLIM & 105.2003 & Anil MARKANDYA and Dirk T.G. RÜBBELKE: Ancillary Benefits of Climate Policy \\
\hline NRM & 106.2003 & Anne Sophie CRÉPIN (1xiv): Management Challenges for Multiple-Species Boreal Forests \\
\hline NRM & 107.2003 & Anne Sophie CRÉPIN (lxiv): Threshold Effects in Coral Reef Fisheries \\
\hline SIEV & 108.2003 & Sara ANIYAR ( lxiv): Estimating the Value of Oil Capital in a Small Open Economy: The Venezuela's Example \\
\hline SIEV & 109.2003 & $\begin{array}{l}\text { Kenneth ARROW, Partha DASGUPTA and Karl-Göran MÄLER(lxiv): Evaluating Projects and Assessing } \\
\text { Sustainable Development in Imperfect Economies }\end{array}$ \\
\hline NRM & 110.2003 & Anastasios XEPAPADEAS and Catarina ROSETA-PALMA(1xiv): Instabilities and Robust Control in Fisheries \\
\hline NRM & 111.2003 & Charles PERRINGS and Brian WALKER (lxiv): Conservation and Optimal Use of Rangelands \\
\hline ETA & 112.2003 & Jack GOODY (lxiv): Globalisation, Population and Ecology \\
\hline CTN & 113.2003 & $\begin{array}{l}\text { Carlo CARRARO, Carmen MARCHIORI and Sonia OREFFICE: Endogenous Minimum Participation in } \\
\text { International Environmental Treaties }\end{array}$ \\
\hline CTN & 114.2003 & Guillaume HAERINGER and Myrna WOODERS: Decentralized Job Matching \\
\hline CTN & 115.2003 & Hideo KONISHI and M. Utku UNVER: Credible Group Stability in Multi-Partner M \\
\hline CTN & 116.2003 & Somdeb LAHIRI: Stable Matchings for the Ro \\
\hline CTN & 117.2003 & Somdeb LAHIRI: Stable Matcl \\
\hline CTN & 118.2003 & Marita LAUKKANEN: Transboundary Fisheries Management under Implementation Uncertainty \\
\hline CTN & 119.2003 & $\begin{array}{l}\text { Edward CARTWRIGHT and Myrna WOODERS: Social Conformity and Bounded Rationality in Arbitrary } \\
\text { Games with Incomplete Information: Some First Results }\end{array}$ \\
\hline CTN & 120.2003 & Gianluigi VERNASCA: Dynamic Price Competition with Price Adjustment Costs and Product Differentiation \\
\hline CTN & 121.2003 & $\begin{array}{l}\text { Myrna WOODERS, Edward CARTWRIGHT and Reinhard SELTEN: Social Conformity in Games with Many } \\
\text { Players }\end{array}$ \\
\hline CTN & 122.2003 & Edward CARTWRIGHT and Myrna WOODERS: On Equilibrium in Pure Strategies in Games with Many Players \\
\hline CTN & 123.2003 & $\begin{array}{l}\text { Edward CARTWRIGHT and Myrna WOODERS: } \text { Conformity and Bounded Rationality in Games with Many } \\
\text { Players }\end{array}$ \\
\hline & 000 & Carlo CARRARO, Alessandro LANZA and Valeria PAPPONET \\
\hline
\end{tabular}




\section{NOTE DI LAVORO PUBLISHED IN 2004}

\begin{tabular}{|c|c|c|}
\hline IEM & 1.2004 & $\begin{array}{l}\text { Anil MARKANDYA, Suzette PEDROSO and Alexander GOLUB: Empirical Analysis of National Income and } \\
\underline{\mathrm{So}}_{2} \text { Emissions in Selected European Countries }\end{array}$ \\
\hline ETA & 2.2004 & Masahisa FUJITA and Shlomo WEBER: Strategic Immigration Policies and Welfare in Heterogeneous Countries \\
\hline PRA & 3.2004 & $\begin{array}{l}\text { Adolfo DI CARLUCCIO, Giovanni FERRI, Cecilia FRALE and Ottavio RICCHI: Do Privatizations Boost } \\
\text { Household Shareholding? Evidence from Italy }\end{array}$ \\
\hline ETA & 4.2004 & Victor GINSBURGH and Shlomo WEBER: Languages Disenfranchisement in the European Union \\
\hline ETA & 5.2004 & Romano PIRAS: Growth, Congestion of Public Goods, and Second-Best Optimal Policy \\
\hline CCMP & 6.2004 & Herman R.J. VOLLEBERGH: Lessons from the Polder: Is Dutch $\mathrm{CO}_{2}$-Taxation Optimal \\
\hline PRA & 7.2004 & Sandro BRUSCO, Giuseppe LOPOMO and S. VISWANATHAN (lxv): Merger Mechanisms \\
\hline PRA & 8.2004 & $\begin{array}{l}\text { Wolfgang AUSSENEGG, Pegaret PICHLER and Alex STOMPER (lxv): IPO Pricing with Bookbuilding, and a } \\
\text { When-Issued Market }\end{array}$ \\
\hline PRA & 9.2004 & Pegaret PICHLER and Alex STOMPER (lxv): Primary Market Design: Direct Mechanisms and Markets \\
\hline PRA & 10.2004 & $\begin{array}{l}\text { Florian ENGLMAIER, Pablo GUILLEN, Loreto LLORENTE, Sander ONDERSTAL and Rupert SAUSGRUBER } \\
\text { (lxv): The Chopstick Auction: A Study of the Exposure Problem in Multi-Unit Auctions }\end{array}$ \\
\hline PRA & 11.2004 & $\begin{array}{l}\text { Bjarne BRENDSTRUP and Harry J. PAARSCH (lxv): Nonparametric Identification and Estimation of Multi- } \\
\text { Unit, Sequential, Oral, Ascending-Price Auctions With Asymmetric Bidders }\end{array}$ \\
\hline PRA & 12.2004 & Ohad KADAN (lxv): Equilibrium in the Two Player, k-Double Auction with Affiliated Private Values \\
\hline PRA & 13.2004 & Maarten C.W. JANSSEN (lxv): Auctions as Coordination Devices \\
\hline PRA & 14.2004 & Gadi FIBICH, Arieh GAVIOUS and Aner SELA (lxv): All-Pay Auctions with Weakly Risk-Averse Buyers \\
\hline PRA & 15.2004 & $\begin{array}{l}\text { Orly SADE, Charles SCHNITZLEIN and Jaime F. ZENDER (lxv): Competition and Cooperation in Divisible } \\
\text { Good Auctions: An Experimental Examination }\end{array}$ \\
\hline RA & 16.2004 & Marta STRYSZOWSKA (lxv): Late and Multiple Bidding in Competing Second Price Internet Auctions \\
\hline CCMP & 17.2004 & Slim Ben YOUSSEF $: \underline{\mathrm{R} \& \mathrm{D} \text { in Cleaner Technology and International Trade }}$ \\
\hline NRM & 18.2004 & $\begin{array}{l}\text { Angelo ANTOCI, Simone BORGHESI and Paolo RUSSU (lxvi): Biodiversity and Economic Growth: } \\
\text { Stabilization Versus Preservation of the Ecological Dynamics }\end{array}$ \\
\hline SIEV & 19.2004 & $\begin{array}{l}\text { Anna ALBERINI, Paolo ROSATO, Alberto LONGO and Valentina ZANATTA: Information and Willingness to } \\
\text { Pay in a Contingent Valuation Study: The Value of S. Erasmo in the Lagoon of Venice }\end{array}$ \\
\hline NRM & 20.2004 & $\begin{array}{l}\text { Guido CANDELA and Roberto CELLINI (lxvii): Investment in Tourism Market: A Dynamic Model of } \\
\text { Differentiated Oligopoly }\end{array}$ \\
\hline NRM & 21.2004 & Jacqueline M. HAMILTON (lxvii): Climate and the Destination Choice of German Tourists \\
\hline NRM & 22.2004 & $\begin{array}{l}\text { Javier Rey-MAQUIEIRA PALMER, Javier LOZANO IBÁÑEZ and Carlos Mario GÓMEZ GÓMEZ (lxvii): } \\
\text { Land, Environmental Externalities and Tourism Development }\end{array}$ \\
\hline NRM & 23.2004 & $\begin{array}{l}\text { Pius ODUNGA and Henk FOLMER (lxvii): Profiling Tourists for Balanced Utilization of Tourism-Based } \\
\text { Resources in Kenya }\end{array}$ \\
\hline NRM & 24.2004 & Jean-Jacques NOWAK, Mondher SAHLI and Pasquale M. SGRO (lxvii):Tourism, Trade and Domestic Welfare \\
\hline NRM & 25.2004 & Riaz SHAREEF (lxvii): Country Risk Ratings of Small Island Tourism Economies \\
\hline NRM & 26.2004 & $\begin{array}{l}\text { Juan Luis Eugenio-MARTÍN, Noelia MARTÍN MORALES and Riccardo SCARPA (lxvii): Tourism and } \\
\text { Economic Growth in Latin American Countries: A Panel Data Approach }\end{array}$ \\
\hline NRM & 27.2004 & Raúl Hernández MARTÍN (lxvii): Impact of Tourism Consumption on GDP. The Role of Imports \\
\hline CSRM & 28.2004 & Nicoletta FERRO: Cross-Country Ethical Dilemmas in Business: A Descriptive Framework \\
\hline NRM & 29.2004 & $\begin{array}{l}\text { Marian WEBER (lxvi): Assessing the Effectiveness of Tradable Landuse Rights for Biodiversity Conservation: } \\
\text { an Application to Canada's Boreal Mixedwood Forest }\end{array}$ \\
\hline NRM & 30.2004 & $\begin{array}{l}\text { Trond BJORNDAL, Phoebe KOUNDOURI and Sean PASCOE (lxvi): Output Substitution in Multi-Species } \\
\text { Trawl Fisheries: Implications for Quota Setting }\end{array}$ \\
\hline CCMP & 31.2004 & $\begin{array}{l}\text { Marzio GALEOTTI, Alessandra GORIA, Paolo MOMBRINI and Evi SPANTIDAKI: Weather Impacts on } \\
\text { Natural, Social and Economic Systems (WISE) Part I: Sectoral Analysis of Climate Impacts in Italy }\end{array}$ \\
\hline CCMP & 32.2004 & $\begin{array}{l}\text { Marzio GALEOTTI, Alessandra GORIA ,Paolo MOMBRINI and Evi SPANTIDAKI: Weather Impacts on } \\
\text { Natural, Social and Economic Systems (WISE) Part II: Individual Perception of Climate Extremes in Italy }\end{array}$ \\
\hline CTN & 33.2004 & Wilson PEREZ: Divide and Conquer: Noisy Communication in Networks, Power, and Wealth Distribution \\
\hline KTHC & 34.2004 & $\begin{array}{l}\text { Gianmarco I.P. OTTAVIANO and Giovanni PERI (lxviii): The Economic Value of Cultural Diversity: Evidence } \\
\text { from US Cities }\end{array}$ \\
\hline KTHC & 35.2004 & Linda CHAIB (1xviii): Immigration and Local Urban Participatory Democracy: A Boston-Paris Comparison \\
\hline KTHC & 36.2004 & $\begin{array}{l}\text { Franca ECKERT COEN and Claudio ROSSI (lxviii): Foreigners, Immigrants, Host Cities: The Policies of } \\
\text { Multi-Ethnicity in Rome. Reading Governance in a Local Context }\end{array}$ \\
\hline KTHC & 37.2004 & $\begin{array}{l}\text { Kristine CRANE (lxviii): Governing Migration: Immigrant Groups' Strategies in Three Italian Cities - Rome, } \\
\text { Naples and Bari }\end{array}$ \\
\hline KTHC & 38.2004 & $\begin{array}{l}\text { Kiflemariam HAMDE (lxviii): Mind in Africa, Body in Europe: The Struggle for Maintaining and Transforming } \\
\text { Cultural Identity - A Note from the Experience of Eritrean Immigrants in Stockholm }\end{array}$ \\
\hline ETA & 39.2004 & Alberto CAVALIERE: Price Competition with Information Disparities in a Vertically Differentiated Duopoly \\
\hline PRA & 40.2004 & Andrea BIGANO and Stef PROOST: The Opening of the European Electricity Market and Environmental Policy: \\
\hline
\end{tabular}


CCMP 41.2004 Micheal FINUS (lxix): International Cooperation to Resolve International Pollution Problems

KTHC $42.2004 \quad$ Francesco CRESPI: Notes on the Determinants of Innovation: A Multi-Perspective Analysis

CTN $\quad 43.2004$ Sergio CURRARINI and Marco MARINI: Coalition Formation in Games without Synergies

CTN 44.2004 Marc ESCRIHUELA-VILLAR: Cartel Sustainability and Cartel Stability

NRM 45.2004 Sebastian BERVOETS and Nicolas GRAVEL (lxvi): Appraising Diversity with an Ordinal Notion of Similarity:

NRM 46.2004 Signe ANTHON and Bo JELLESMARK THORSEN (lxvi): Optimal Afforestation Contracts with Asymmetric

Information on Private Environmental Benefits

NRM 47.2004 John MBURU (lxvi): Wildlife Conservation and Management in Kenya: Towards a Co-management Approach 
(lix) This paper was presented at the ENGIME Workshop on "Mapping Diversity", Leuven, May 1617,2002

(lx) This paper was presented at the EuroConference on "Auctions and Market Design: Theory, Evidence and Applications", organised by the Fondazione Eni Enrico Mattei, Milan, September 2628,2002

(lxi) This paper was presented at the Eighth Meeting of the Coalition Theory Network organised by the GREQAM, Aix-en-Provence, France, January 24-25, 2003

(lxii) This paper was presented at the ENGIME Workshop on "Communication across Cultures in Multicultural Cities", The Hague, November 7-8, 2002

(lxiii) This paper was presented at the ENGIME Workshop on "Social dynamics and conflicts in multicultural cities", Milan, March 20-21, 2003

(lxiv) This paper was presented at the International Conference on "Theoretical Topics in Ecological Economics", organised by the Abdus Salam International Centre for Theoretical Physics - ICTP, the Beijer International Institute of Ecological Economics, and Fondazione Eni Enrico Mattei - FEEM Trieste, February 10-21, 2003

(lxv) This paper was presented at the EuroConference on "Auctions and Market Design: Theory, Evidence and Applications" organised by Fondazione Eni Enrico Mattei and sponsored by the EU, Milan, September 25-27, 2003

(lxvi) This paper has been presented at the 4th BioEcon Workshop on "Economic Analysis of Policies for Biodiversity Conservation" organised on behalf of the BIOECON Network by Fondazione Eni Enrico Mattei, Venice International University (VIU) and University College London (UCL), Venice, August 28-29, 2003

(lxvii) This paper has been presented at the international conference on "Tourism and Sustainable Economic Development - Macro and Micro Economic Issues" jointly organised by CRENoS (Università di Cagliari e Sassari, Italy) and Fondazione Eni Enrico Mattei, and supported by the World Bank, Sardinia, September 19-20, 2003

(lxviii) This paper was presented at the ENGIME Workshop on "Governance and Policies in Multicultural Cities", Rome, June 5-6, 2003

(lxix) This paper was presented at the Fourth EEP Plenary Workshop and EEP Conference "The Future of Climate Policy", Cagliari, Italy, 27-28 March 2003 


\section{SERIES}

CLIM Climate Change Modelling and Policy (Editor: Marzio Galeotti )

GG Global Governance (Editor: Carlo Carraro)

SIEV Sustainability Indicators and Environmental Valuation (Editor: Anna Alberini)

NRM Natural Resources Management (Editor: Carlo Giupponi)

KNOW Knowledge, Technology, Human Capital (Editor: Gianmarco Ottaviano)

IEM International Energy Markets (Editor: Anil Markandya)

CSRM Corporate Social Responsibility and Management (Editor: Sabina Ratti)

PRIV Privatisation, Regulation, Antitrust (Editor: Bernardo Bortolotti)

ETA Economic Theory and Applications (Editor: Carlo Carraro)

CTN Coalition Theory Network

\section{SERIES}

CCMP Climate Change Modelling and Policy (Editor: Marzio Galeotti )

GG Global Governance (Editor: Carlo Carraro)

SIEV Sustainability Indicators and Environmental Valuation (Editor: Anna Alberini)

NRM Natural Resources Management (Editor: Carlo Giupponi)

KTHC Knowledge, Technology, Human Capital (Editor: Gianmarco Ottaviano)

IEM International Energy Markets (Editor: Anil Markandya)

CSRM Corporate Social Responsibility and Management (Editor: Sabina Ratti)

PRA Privatisation, Regulation, Antitrust (Editor: Bernardo Bortolotti)

ETA Economic Theory and Applications (Editor: Carlo Carraro)

CTN Coalition Theory Network 